needed to be exhausted, farming families preferred to send a family member outside the village, prefecture, or country... [T] he peasants' reluctance to transform themselves into pure cultivators of cane can be understood as a significant act of anti-capitalist refusal that obstructed the transformation of their work and lives into dead labor, a process that would have remade them into alienated producers of raw materials or sellers of their labor power (144-145).

Economic conditions in what is still the nation's poorest prefecture compelled many Okinawans to emigrate to mainland Japan, to territories in the South Seas that were part of the Japanese colonial empire until 1945, and to Hawaii and the Americas. In cities on the mainland, where employment and housing discrimination against Okinawans was severe, migrants formed organizations such as the Kansai Okinawa Prefectural Association in Osaka, which is still home to the largest Okinawan diaspora in Japan. Its goals were "the mutual relief of members, the integration of members, the integration of the people of the prefecture and their progress" (Quoted on 159).

Its projects included providing refuge from natural disasters, treating illness, providing introductions to potential employers, providing help during periods of unemployment, maintaining communications with Okinawa, holding funerals and officiating at weddings. At the same time its leaders educated workers in Marxist-Leninist thought so as to equip them with knowledge of the importance of participating in strikes and fighting against their employers (159).

Leaders who returned to Okinawa in the early 1930s helped organize villagers in northern Okinawa fighting to alleviate tax burdens and transfer control of communal resources to local residents. Matsumura concludes: "The political victories that these participants were able to win, and the transformation of their demands and desires through the process of struggle, created enormous difficulties for state leaders who hoped that the northern periphery of Okinawa would remain nothing more than a source of cheap labor power that could be funneled into factories" (180).

Steve Rabson

Brown University

\title{
Remi Kanazi, Before the Next Bomb Drops: Rising Up from Brooklyn to Palestine (Chicago: Haymarket Books, 2015). 100pp. Paperback \$16.00.
}

Remi Kanazi's newest collection of poetry is a work of resistance born out of our immediate political moment. A poet, writer, and organizer based in New York City, Kanazi writes about the lives of Palestinians under occupation and as refugees around the world. He previously authored the collection Poetic Injustice: Writings on 
Resistance and Palestine (RoR Publishing, 2011) and edited the anthology Poets for Palestine (Al Jisser Group, 2008). Readers familiar with the "poetry of resistance," produced by iconic Palestinian poets such as Mahmoud Darwish and Samih al Qasim, will recognize some points of continuity in Kanazi's contemporary protest poetry. The volume opens, for instance, with "Nakba," an allusion to the "catastrophe" of 1948, seen here through the eyes of a young Palestinian woman, "seven months pregnant," forced to flee her homeland (1). Despite her own and her people's dispossession, the poem is no elegy. Inspired by "their mother / that warrior," her daughters vow never to forget:
we will return
that is not a threat
not a wish
a hope
or a dream
but a promise (4)

"Nakba" is one of a handful of traditionally lyrical meditations that anchor the collection. These poems stand out in terms of their more restrained style and their emphasis on the long history of the movement for Palestinian human rights. "We cannot / be erased," Kanazi writes in "Refugee," one of the volume's most ambitious poems. In "Sumoud," he introduces us to Ahmed, "studying abroad / father caged at home" (67), a second-generation activist now finding his own place in the struggle for Palestinian liberation:
divest. roars from his diaphragm
he builds mock checkpoints
erects wall panels so students
can witness a hint
of his existence (67-68)

Kanazi currently serves as a member of the Advisory Committee of the Palestinian Campaign for the Academic and Cultural Boycott of Israel, and many of his poems document this global movement from the perspective of its student leaders. This is the most distinctive and urgent aspect of Before the Next Bomb Drops: Kanazi displays a unique ability to capture the ambitions and frustrations of a new generation of student activists.

From Israeli violence in Palestine, Kanazi shifts his focus to U.S. state violence, police brutality, racism, and Islamophobia. By juxtaposing Gaza and Ferguson, Baghdad and Brooklyn, Before the Next Bomb Drops provides a framework for considering the connections among various global movements for human rights and social justice. A focus on contemporary media unites these seemingly disparate 
and diasporic poems. "Intersecting systems of oppression get no airtime," Kanazi tells us in "Nothing to Worry About" (14). In "Until It Isn't," he criticizes social media's appetite for destruction, what he terms "suffering 2.0":

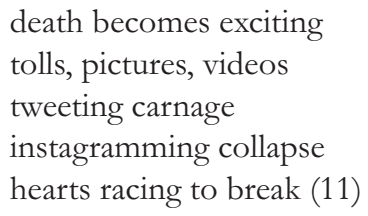

Kanazi repeatedly warns against the complacency of so-called hashtag activism"\#solidarity" - and encourages activists to dedicate themselves to the difficult work of community building. However, despite his concerns about social media as a platform for social justice, Kanazi is clearly inspired by the new coalitions that new media has made possible since the uprising in Cairo in 2011. "Palestine is not Ferguson," Kanazi writes in "\#What Remains,"

it is not the same, but the swollen eyes the stuttering breath, the anger rushing through the corridors of our bones feels so familiar. \#Palestine2Ferguson (53)

When read together, these poems provide an effective primer for young activists: take off your noise-canceling headphones, Kanazi advises, and confront your own complicity. Because of their didacticism, the poems are perfectly suited for classroom conversation. I am especially eager to find out how my students will respond to Kanazi's characterization of the current state of campus activism:

\author{
students are coming \\ and they aren't stopping \\ cowering \\ caving \\ to veiled threats, stripped funding \\ and attacks on their organizations (45)
}

There is little subtlety to be found in Before the Next Bomb Drops. But, what Kanazi lacks in grace, he makes up for in the strength of his convictions. "I would rather be labeled / an angry Brown poet / than be an apathetic American," he writes in "Tone It Down" (86). This style of politically assertive, identity-based poetry has become the preferred mode of "slam" or performance poets in recent years. Kanazi's poems read well on the page, but they truly come alive in performance. Anyone interested in learning more about Kanazi's poetry should seek him out on 
YouTube, where the dynamic nature of his political performance art is in ample evidence.

Melissa Girard Loyola University Maryland

Barry Wright, Eric Tucker, and Susan Binnie, eds., Security, Dissent, and the Limits of Toleration in War and Peace, 1914-1939, Canadian State Trials, vol. IV (Toronto: University of Toronto Press, 2015). xv+517pp. Hardcover $\$ 50.00$.

This important volume of eleven essays and three appendices carries the extraordinary Canadian State Trials (CST) project resolutely on to the terrain of Hobsbawm's Age of Extremes, the Short Twentieth Century. This collection is the fourth in the series that commenced with Law, Politics and Security Measures, 1608-1837 (1996) and was followed by Rebellion and Invasion in the Canadas, 1837-1839 (2002) and Political Trials and Security Measures, 1840-1914 (2009). The late F. Murray Greenwood began the path-breaking project in the 1990s and co-edited the first two volumes before his death in December 2000. His co-editor on those volumes, Barry Wright, has continued with co-editors Susan Binnie on volumes III and IV and Eric Tucker on volume IV.

The rationale for the series, and a fascinating account of its 18 th and 19 th century British predecessors, appeared in the first volume:

The way is open to return to the tradition of the libertarian state trial editors, where a critical eye may be cast at the contradictions between repressive or partisan practices and claims made about the impartiality of the law...Security cases highlight an ongoing tension between the rule of law and the discretionary exercise of executive measures and reveal something about the role of law in the exercise of power.

(CST, I, 9)

Wright has consistently maintained the breadth of interpretation established in the wide selection of material for inclusion under the rubric "state trials" and has also continued the valuable addition of archival explanation and commentary (Judi Cumming), as well as a selection of major legal documents. Indeed, in the case of this volume, such additional materials are extended to include an analysis of the significant problems faced by researchers owing to Canada's sadly out-dated Access to Information legislation (Patricia I. McMahon).

Following an excellent introduction by the editors, the essays fall into three unacknowledged groupings: four on the crises of World War I, three related to the post war Labour Revolt, and three on state repression of labour and the left during the Depression. An eleventh essay by John McLaren on the trials and near deportation of Doukobor leader Peter Verigin might loosely be associated with the latter 